Journal of Education and Vocational Research

Vol. 1, No. 3, pp. 87-95, June 2011

\title{
Used Bookstore as a Vehicle for Improved Learning and Development: The Case of a South African
} Tertiary Institution

\author{
Chux Gervase Iwu*, Dumisani Xesha \\ Department of Entrepreneurship \& Business Management, Faculty of Business, Cape Peninsula University of \\ Technology, South Africa \\ *iwuc@cput.ac.za
}

\begin{abstract}
In South Africa, the capability of tertiary institutions to provide the best possible education to its students is hindered by financial difficulties. Determining how to make a place of learning more accessible takes decent consideration for the needs and wants of students as well as management. Most South African tertiary institutions have large numbers of students who are faced with challenges of learning. A major challenge that this study highlights is that of the short supply of and access to both prescribed and recommended textbooks. Short supply refers to the library not acquiring enough support texts that go round, while access refers to the lack of funds by the student to own a prescribed or recommended text book. The study sample was derived from the business faculty of a South African university of technology. In order to get a representative sample, 300 business students were randomly chosen. Out of this number, only 157 usable questionnaires were returned. The results indicated, amongst others, that the majority of the participants come from less fortunate backgrounds and as a result sought support from several sources for their studies. This is a strong indication that given the cheaper cost of textbooks, these students will favor a secondhand book store. This study explored the possible contribution to teaching, learning and academic development by a used book store. The findings indicated that a used bookstore would provide enormous support to student learning and development. This paper's significance stems from its originality given that it is the first time that attention is paid to this serious issue of teaching and learning challenges in this regard.
\end{abstract}

Keywords: Used bookstores, South Africa, Teaching, Learning, Higher Education, University of Technology

\section{Introduction and Literature}

Education is one of the primary means for the development of understanding and more harmonious interaction which facilitates the reduction of poverty, exclusion, ignorance, oppression and war (UNESCO, 1996). This indicates that if students are not properly educated and developed, the development of a nation will not advance. The university is a primary tool for modern nation building (Poole, 2004). Harber and Mncube (2011) argue that education is vital for the development of South African society. According to these authors, education has the capacity to enrich individuals with knowledge, skills and values which can be of great benefit to both the individual and the nation. Thus schooling prepares the youth for the future, to become wise leaders and have personal achievement.

For education to be effective, students need to have access to its basic tools to study. These basic tools include textbooks and all instructional materials. Makgato and Mji (2006) contend that certain reasons account for student failure. Some of these reasons include inadequate infrastructure, lack of relevant study materials and poorly trained teachers. Over the years lecturers and those involved in the tertiary level education in South Africa have shared their unhappiness over the poor performance of students, especially those coming from disadvantaged backgrounds. There are various factors that might have contributed to this poor performance. The list of factors would forever continue as different universities around the world are faced with their unique challenges in their operational environments. Poor performance is indicated through low marks achieved by students. This somewhat confirms that learning has not taken place. Learning processes cannot be observed or studied (Bergh \& Theron, 2009: 74). To 'observe' if learning has taken place requires an assessment of performance. Tertiary institutions in South Africa are centers of learning and development. They support government's mission of advancing the socio-economic development of the nation through the enhancement of the skills of the citizens of the nation. If students do not perform well, these objectives may not be realized. According to the Department of Higher Education and Training ((DHET, 2010) the system 
must ensure that the skills needed to drive the country's economic growth and social development are delivered at an increasing rate, because available, quality skills will enhance both investment and service delivery.

Education is linked to nation development. It improves productivity, health and reduces negative features of life such as child labour as well as bringing about empowerment (Otive, 2006: 1). A large portion of the students at the institution under review come from disadvantaged backgrounds. They not only struggle for subsistence, they also struggle to access funding for tuition. Beyond funding for tuition, the students also struggle to afford both prescribed and recommended textbooks. The library's lack of capacity to stock enough books also makes it difficult for the students to access textbooks. The acquisition policy of the university library does not give room for the purchase and or acquisition of more than three (3) copies of prescribed materials. When these materials are acquired, they can not only be consumed within the premises of the library, which means they are placed on short loans. As a result of this, many of the financially needy students in this institution become discouraged and de-motivated to learn as the needed resources are unaffordable. This in turn results in poor attendance which causes high failure rate. The need for a used book store is therefore significant in this situation as it will provide a low cost alternative to students.

An independently managed book store that supplies a limited amount of new books at retail price is a common site in many tertiary institutions. These book stores grapple with demand and supply issues. Students have to wait for a considerable amount of time before receiving their chosen books for their subjects. This used bookstore, it is argued, would provide a good alternative as there will constantly be a sufficient supply of used books available to the students. The availability of used textbooks could be the most important factor in predicting academic achievement to the students that previously struggled to gain the proper sources of literature. Samantha (2010) insists that the concept of used textbooks is widespread over the market these days. They are considered to be the most suitable alternative that is economically feasible and convenient to acquire, particularly at the tertiary education level. As far back as 1998, the South African Institute of Race Relations (SAIRR) had identified the gap between supply and demand of skilled people in South Africa. Their finding suggested that previously disadvantaged South Africans were affected mostly by the previously skewed education system. National Student Financial Aid Scheme (NSFAS) (2009) also noted that access to education and the quality of education had been contentious issues for decades in South Africa. Issues around funding for tuition mean that large numbers of students from disadvantaged backgrounds at tertiary institutions use NSFAS to fund their studies (CHE, 2004). The government established the NSFAS in 1996 to ensure that academically able students who are without financial resources can attain higher education. The scheme, administered by Tertiary Education Financial Student Assistance (TEFSA), also raises funds, recovers loans and conducts research for the better utilization of financial resources (NSFAS, 1999).

\section{The Case of South Africa}

The revised strategic plan (2010-2015) of the South African Department of Higher Education and Training (DHET, 2010) states, inter alia, that government must provide quality learning wherever learning takes place be it at a college, a university or in the workplace; ... Access to university education for many qualifying youth is still a serious problem due to inadequate infrastructure, lack of funding and rigid admission requirements by some of the universities. While government has eased access to South African colleges and universities for students especially from poor families through the awarding of bursaries and loans to qualifying learners, colleges and universities still experience poor pass rates. When a student does not have access to study materials and he is running behind on assignment submission, there is a tendency to copy without acknowledging his source. If such a student is caught plagiarizing, he either gets no mark or gets a very low mark, which consequently affects the student's morale. The Department of Higher Education and Training (DHET. 2011) acknowledges that the rate of student drop out has increased in South Africa. This, the department claims, can be attributed to the lack of support materials as well as a noticeable absence of adequate career guidance and information. The following problems are the basis of this study;

- Poor pass rate

- Acts of plagiarism

- Late submission of assignments

- Lack of textbooks 
- Large portion of students in the institution come from disadvantaged backgrounds thus there is the challenge of buying prescribed and recommended text books

- The defacing of lecture rooms and walls of buildings with notices for used books

Given the above problem statements, this study pursued answers to the following research questions:

- Is there a likelihood that students performance (pass rate, late submission of assignments) will improve if learning materials (in this case, text books) are easily affordable;

- Is there likelihood that defacing library books as well as copying can be minimized if students had access to prescribed books at affordable prices?

Following are objectives of the study which help to answer above mentioned questions

- Explore the concept of a used book store as a facilitator of students learning and research experience

- The ownership of books could reduce the trend of copying, plagiarism and defacing of library books

- Create a positive outcome for tertiary institution's throughput

- A positive outcome could be tertiary institutions' resolve to set up used book stores

The South African Department of Higher Education and Training in 2010 acknowledged that there was limited research available that provided a nuanced picture into tertiary education systems and their strengths and weaknesses (DHET, 2010). The department also urged academics and research organizations to identify their own research questions and conduct relevant research on tertiary institutions and the skills training system in general. This study thus adds value in the sense that it provides a discussion of some of the challenges of learning and development as well as some possible solutions.

\section{Research Methodology}

This study focused on a South African university of technology. Students of the institution at various departments in the Business Faculty were monitored over two semesters (1 year). The main reason for this monitoring was to analyze student performance and discover the reasons for the poor performance of students in the institution. Four indicators were noticed during this analysis namely poor pass rate, acts of plagiarism that go against university regulations, late submission of assignments, and lack of textbooks. Considering that the study was the first of its kind, validity of the survey instrument was tested utilizing a pilot sample of 16 students and 4 academics. The academics were specifically asked to evaluate the instrument against the objectives of the study. This was done in order to ensure that the respondents reacted objectively to the questions. Aside from checking whether the students connected reasonably well with the questions, the facilitators reported that the length of time for filling out each questionnaire was longer than anticipated. This was an important consideration especially considering that the proper survey would take place during class time. The result of the pilot indicated a need to reframe the questions as well as reduce the number of questions. To allow for a faster survey and ensure that questions were not unduly ambiguous, the decision was taken to support the reframing and reduction of the number of questions.

This study used both the quantitative and the qualitative research methods. These methods were chosen by the researcher in an effort to view the matter under investigation from different perspectives. Qualitative research methodology includes focus groups, individual interviews and in-depth interviews. Qualitative approach is subjective in nature and involves examining and reflecting on perceptions so as to understand the social and human activities (Collins \& Hussey, 2003: 152). The purpose of quantitative research methodology is to evaluate objective data consisting of numbers (Wellman \& Kruger, 2005: 8). Primary research sources such as surveys and observations were used in this study. A survey is a research method of collecting data from a sample of participants drawn from a larger population through the use of a standardized questionnaire (Wellman \& Kruger, 2005). In the case of observation, the researcher observed the defacing of lecture rooms and walls by students who put up notices indicating interest in used books. There were also notices from students who wished to sell their used books.

Data Collection: Due to time constraints and availability of the students, the population of this study was restricted to the Business Faculty whereby a sample $(n)$ of 300 students was targeted. The sample was 
randomly chosen in order to ensure a reasonable degree of fair representation of students who were genuine Faculty of Business students. An e-mail request was first sent to academic staff in the faculty to indicate their willingness to allow the facilitators to come into their classes and distribute the questionnaires. This meant that lecture times (approximately 10 minutes) would be utilized for students to complete the questionnaires. With the consent of the lecturers in place, an agreement was reached that the distribution of the questionnaires should take place only during the second lectures of the mornings. The facilitators were then urged to randomly access lecture rooms. A total of 300 questionnaires were distributed. However, 157 questionnaires of them were returned fully and correctly filled out. These questionnaires consisted of closeended questions, whereby a participant would have a choice of saying Yes or No. The students volunteered to participate as the researcher was aware of the ethical considerations in relation to individual rights, dignity, as well the freedom of choice.

Aside from demographics, the questions posed included:

- Do you buy new textbooks?

- Would you be willing to buy old textbooks?

- On completion, would you be willing to sell your books?

- Is the library's collection sufficiently helpful?

- In the event that you are unable to access the library, what other alternatives are there for completing assignments?

The validity of the questionnaires was preliminarily assured from a focus group of five students from the Faculty of Business, and the results showed a common understanding on the matter of interest. After the data was collected from the participants, the information was presented in a graphic form, in order to infer results (refer to the Figures under the findings section). Data gathered were analyzed into descriptive statistics using MS Excel. The presentation of the findings is mainly in the form of frequency graphs and percentages.

\section{Findings}

Total three hundred (300) questionnaires were distributed to the students from the business faculty, and 157 questionnaires were returned fully and correctly filled out. The findings of the study follow:

Nationality: The graph below displays the nationality of participants surveyed;

Figure: 1- Nationality of participants

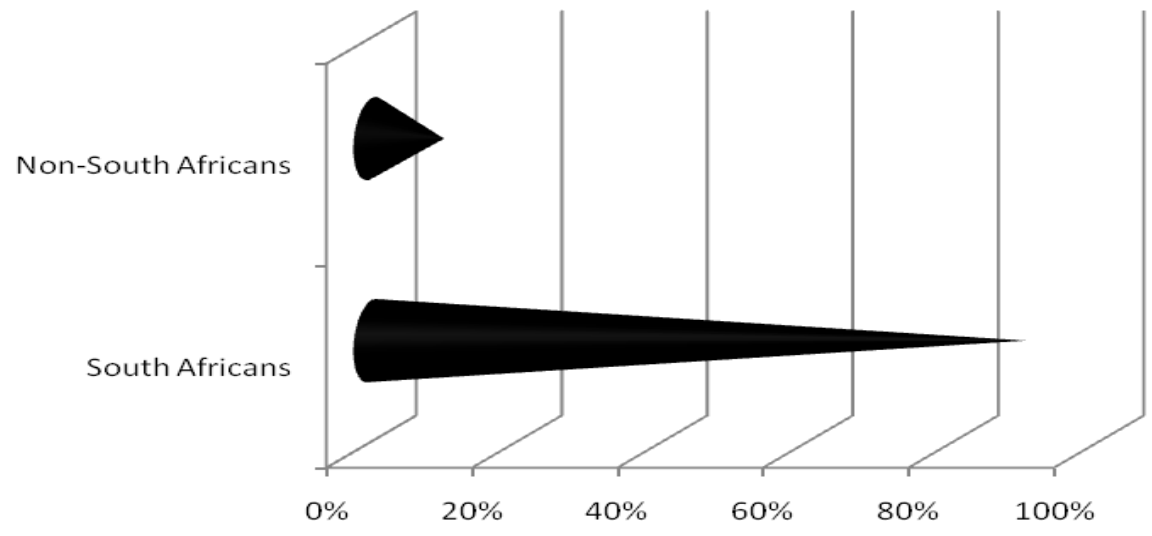

Ethnicity: Out of the 157 usable questionnaires, 52 of them came from Black Africans. This represented 33.12 per cent of the sample. Colored represented 31.2 per cent of the sample, which meant 49 of the 157 usable 
questionnaires. Number of Indians who completed the questionnaires was 33 or 21 per cent of the sample, while 23 white students or 14.6 per cent of the sample completed the questionnaires.

Study Support: Figure 2- below shows the different kinds of sources of financial support that students use for their studies:

\section{Figure 2: Study support sources of finance}

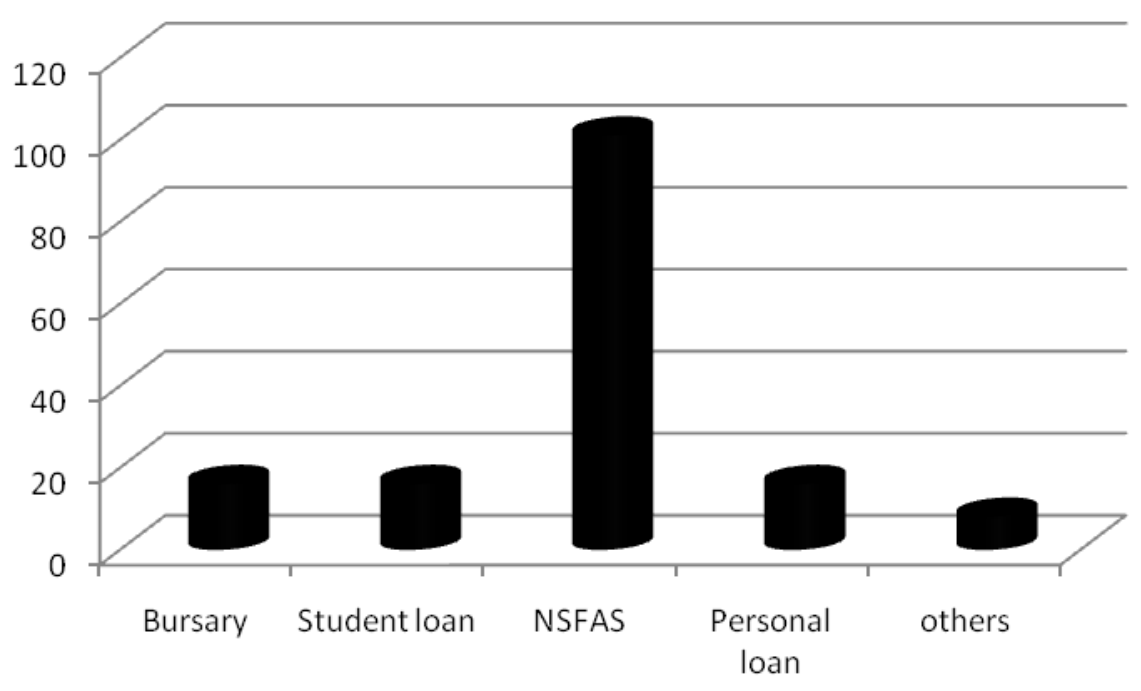

Figure: 3 Library books to students

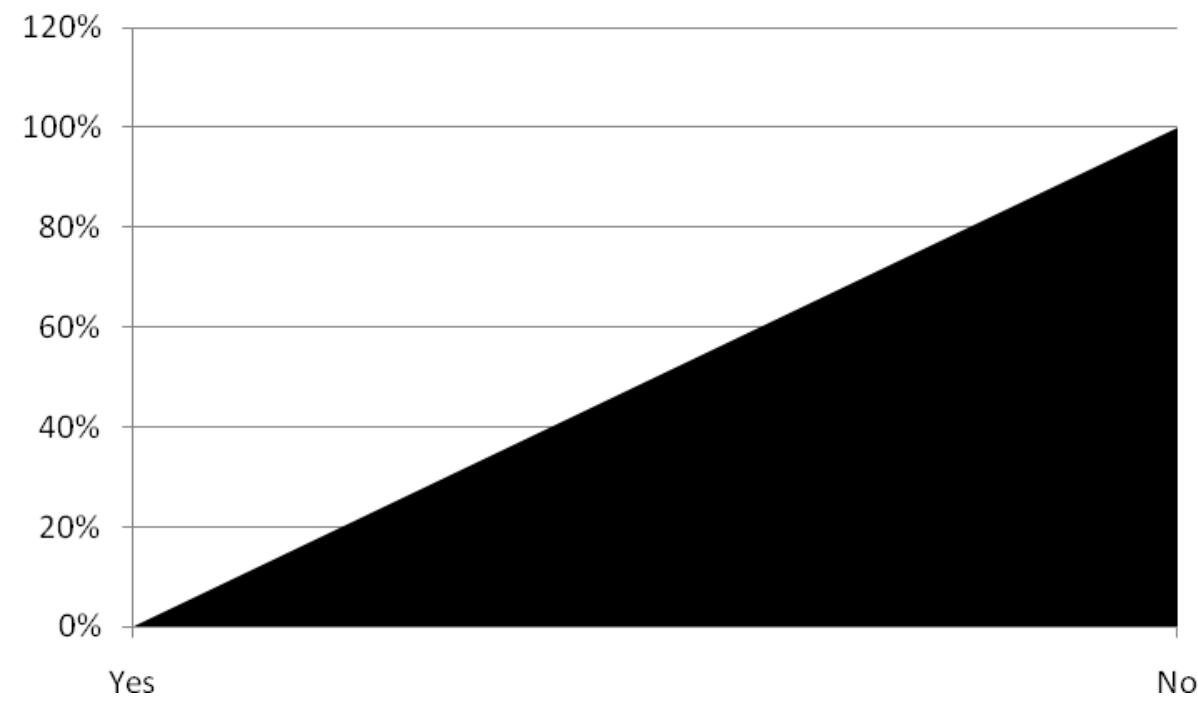


Figure 4: Alternative to textbooks

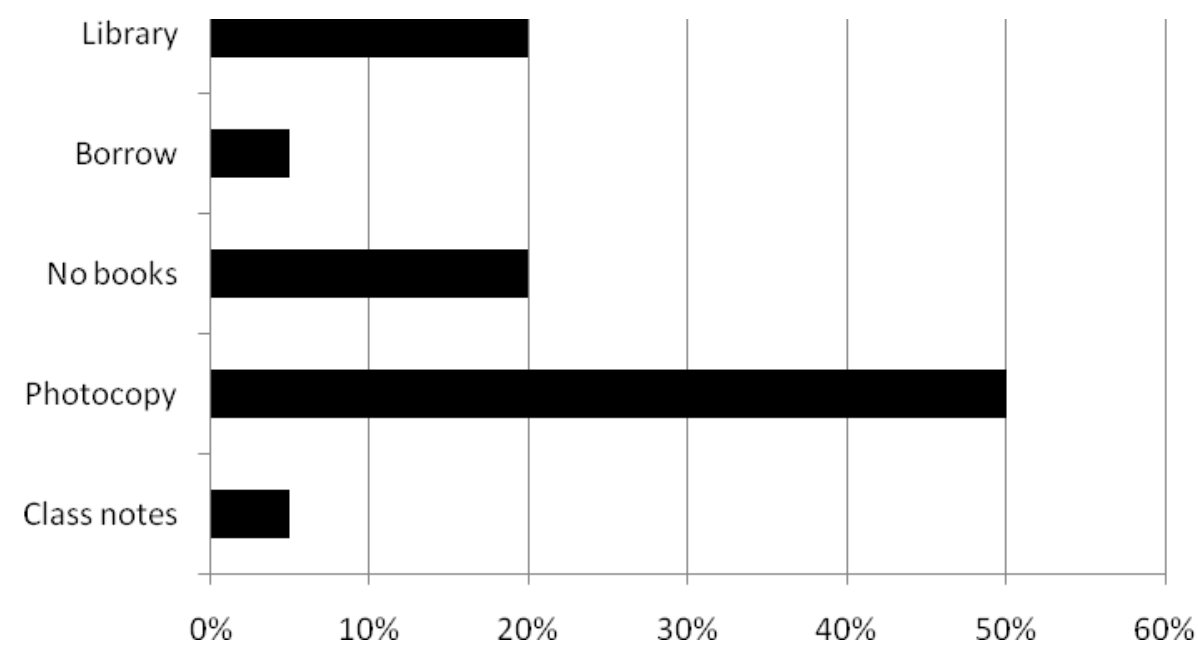

Do you buy brand new textbooks? The figure below depicts the responses of the students, when asked if whether they buy brand new textbooks:

Figure 5: Do you buy brand new textbooks?

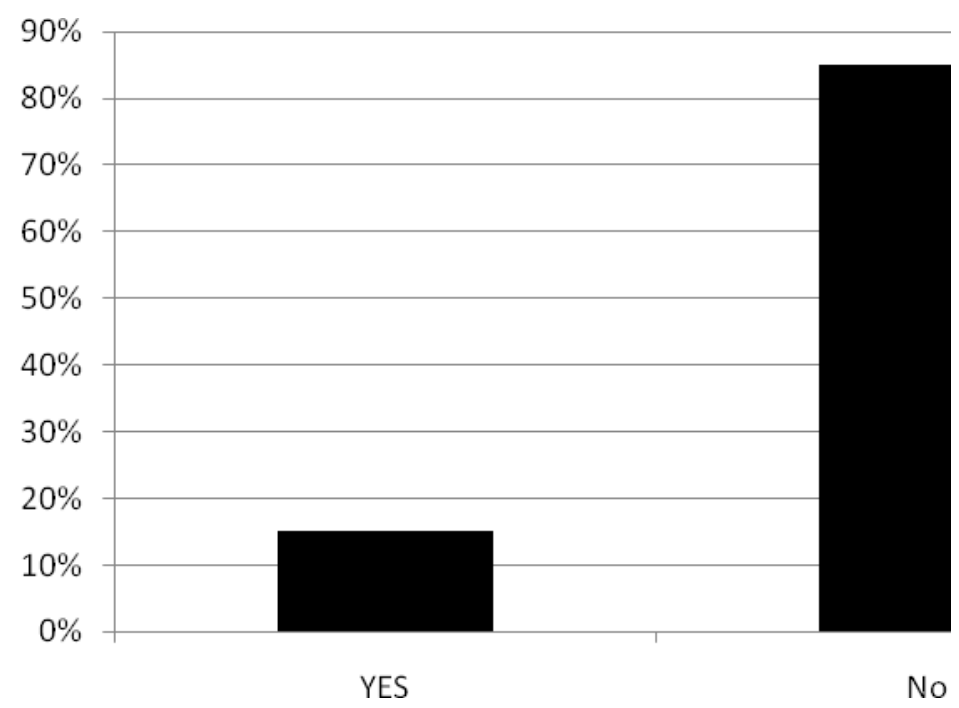

Will you buy used books?: The figure below depicts the students responded when they were asked if whether they would buy used books; 
Figure 6: Will you buy used textbooks?

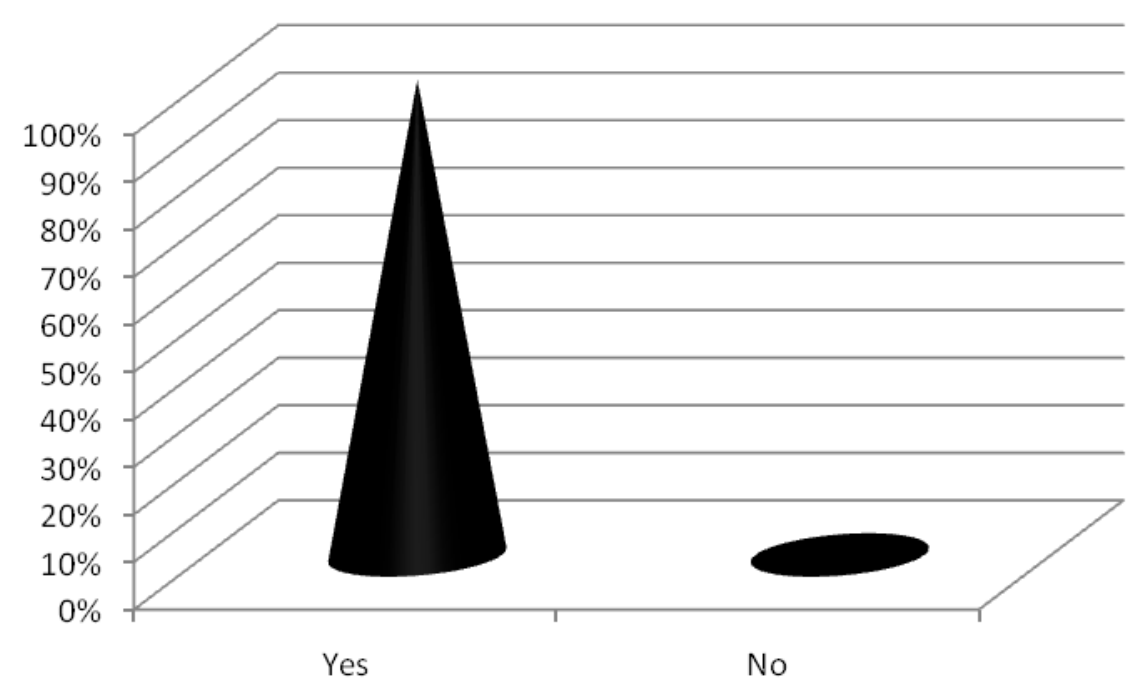

Will you be selling your textbooks? : The figure below depicts response of the students when they were asked if they would sell their textbooks after the course of your study?

Figure 6: Will you be selling your textbooks?

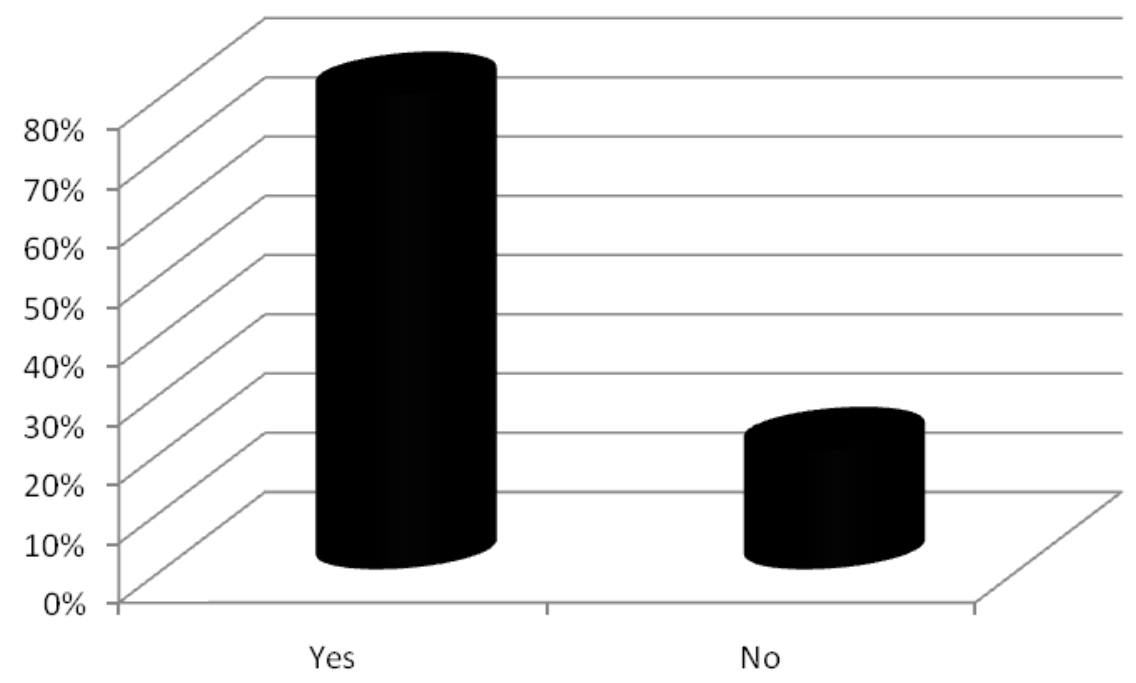

Analysis of the Findings: The majority of the participants in the study were South Africans at 90 percent. 10 percent were non South Africans. The ethnicity of the participants was as follows: 52 Black Africans, 23 Whites, 33 Indians, and 49 were colored. The kinds of Study Support sources of financial support used by participants of the study were as follows: 16 are using Bursaries, 16 Student Loan, 101 NSFAS, 16 Personal Loan, and 8 are using other sources of funds. The other possible alternatives other than textbooks that participants use are as follows: 5 percent use Class Notes, 50 percent photocopy materials, 20 percent No books, 5 percent Borrow from others, and 20 percent use the library. The responses of the students, when asked if whether they buy brand new textbooks showed that only 15 percent buy new textbooks and 85 percent do not. Following this response, it was therefore not surprising that majority of the participants 
indicated a willingness to buy used textbooks. When asked whether they would sell their books after completing their study, 20 per cent would not whereas 80 per cent indicated a willingness to sell. The results show that the majority of the participants come from less fortunate backgrounds and a result seek support from several sources for their studies. This is a strong indication that given the cheaper cost of textbooks, these students will favor a secondhand book store.

\section{Recommendations and Concluding Remarks}

This study has determined the importance of access to data and information, in the learning and development of a student at a tertiary institution. The findings have also indicated that a large number of students make use of information sources other than new textbooks. One can therefore infer that students are unable to afford new textbooks and would rather make use of alternatives. The use of NSFAS and other support agencies by a large number of students is an indication that most students rely on these agencies for tuition fee support. This thus indicates a need for a used bookstore. The lack of access to reading material limits an individual's ability to sufficiently develop his knowledge in an unfavorable learning environment. There is a need for a used book store in this institution. This bookstore can serve a plethora of purposes. Various departments at the institution under study would be able to utilize the used book store towards academic disciplines and projects.

The first thing that needs to be established is the premises of the used book store. Once that has been allocated, the Interior Design students could work towards designing the layout of the book store which could change on an annual basis and any added concepts such as lighting and so forth can be done by the Industrial Design students. The marketing of the used bookstore can be under the control of the Marketing department of which any advertising materials such as posters and promotions can be operated by them. The printing department could be utilized to control the operations of poster printing, flyers and any other material that is deemed necessary. The Auditing department can maintain the finances of the used book store by managing its financial status and investing the small profit that the used book store generates to create opportunity for a bigger and better used book store. The Project Management department would fundamentally be the single point of responsibility for managing the various departments by setting the job scope and due dates and so forth.

The Entrepreneurship department can constantly come up with innovative ways of adding new and advanced features into the bookstore. As with many used bookstores, selling of music, clothes, jewellery and tea, coffee and cakes is fashionable which eventually can be implemented allowing Sound Engineering students to compile musical albums, while Informatics and Design students can sell their pieces and Hotel students can sell their sweet and savory cakes and bakes. Overall the used bookstore will not only supply learning materials to the students but will also create opportunity for practical experience and in essence all those involved in the used book store will have a sense of entrepreneurial adventure.

\section{Consideration for Further Study}

The questionnaire did not ask the sample to justify their responses. It might help with future study to aim for a justification of responses because much clarity can be obtained regarding the specific reasons behind answers to questions such as 'would you give up your textbook on completion of your course?, what other alternatives exist in the event that the library materials are not sufficient?, would you buy old textbooks? Another angle that a future study can pursue is to ask the question, how dated are used textbooks? This research is aware of studies (Ghose, Smith, \& Telang, 2006; Illobre, 2008; Savikas, 2009) that have indicated that the internet is possibly cannibalizing print sales. It might help to examine the degree at which the socalled cannibalization through the sale of used books impact the authors and publishers of books. It might also help to observe if an improvement is achieved after a year of study by monitoring throughput in the institution under study. This is predicated though on the used book store being set up at the institution. 


\section{References}

Bergh, C. Z. \& Theron, L. A. (2009). Psychology in the Work Context (4e). Oxford University Press.

CHE (2010). Higher Education Finance and Cost-Sharing in South Africa. Retrieved October 12, 2010 from http://gse.buffalo.edu/org/inthigheredfinance/files/Country_Profiles/Africa/South_Africa.pdf.

Collins, J. and Hussey, R. (2003) Business Research: a practical guide for undergraduate and postgraduate students. 2nd Edition. Basingstoke: Palgrave Macmillan

DHET (2010). National Skills Development Strategy 111. Retrieved June 14, 2011 from http://www.dhet.gov.za/LinkClick.aspx?fileticket=nnfc2uv80FI\%3d\&tabid=36\&mid=1071.

Ghose, A., Smith, M. D., \& Telang, R. (2006). Internet exchanges for used books: an empirical analysis of product cannibalization and welfare impact. Information Systems Research, 17(1), 3-19.

Harber, C. \& Mncube, V. (2011). Is schooling good for the development of society? the case of South Africa. South African Journal of Education, 31, 233-245.

Henning, E. (2004). Finding your way in Qualitative Research. Pretoria: Van Schaik.

Illobre, N. (2008). Fear of Cannibalization. The Primary Barrier to Media Domination. Retrieved March 18, 2011 from http://www.spoig.com/l.c.bin/F/15045114/SPOIG_Cannibalization.pdf

Makgato, M. \& Mji, A. (2006). Factors associated with school learners' poor performance. A spotlight on Mathematics and Physical Science. South African Journal of Education, 26(2), 253-266.

Mncube, V. S. \& Harber, C.R. (2010). Chronicling educator practices and experiences in the context of democratic schooling and quality education. International Journal of Educational Development, 30, 614-624.

NSFAS (2010). Annual Report 2010. Retrieved October 16, 2010 from https://www.nsfas.org.za/web/view/general/reports/annualreport2010.

Otive, I. (2006). The state of education in Nigeria. A keynote address delivered at a roundtable organized by civil society coalition on education for all. July 3, 2006. Action Aid International, Nigeria. Retrieved May 26, 2011 from http://www.dawodu.com/igbuzor14.htm

Poole, M. (2004). Diversity of the student body and social cohesion. Paper presented at the IAU Sao Paulo $12^{\text {th }}$ General Conference: The Wealth of Diversity. July 25 - 29, 2004.

Samantha, W. (2010). Significance of Used Text Books. Retrieved October 10, 2010 from http://www.articledashboard.com/Article/Significance-of-used-text-books/1848641.

Savikas, A. (2011). Does digital cannibalize print? Not yet. Retrieved May 24, 2011 from http://radar.oreilly.com/2009/08/does-digital-cannibalize-print-not-likely.html.

Spreen, C. \& Vally, S. (2006). Education rights, education policies and inequality in South Africa. International Journal of Educational Development, 26, 352-362.

UNESCO (1996). Learning the treasure within. Report to the UNESCO commission on education for the $21^{\text {st }}$ century. Paris. Retrieved May 26, 2011 from http://www.education.unesco.org/pdf/1562.pdf.

Wellman, J. C. \& Kruger, S. J. (2005). Research Methodology for Business and Administrative Sciences. $3^{\text {rd }}$ Edition. Cape Town: Oxford University Press. 